\title{
Environmental Effects of Water Quality of Melendiz Stream and Mamasin Dam Site in Aksaray City in the Central Anatolia of Turkey
}

\author{
Hatim Elhatip and Hasan Koçyiğit \\ Department of Environmental Engineering, University of Aksaray, Aksaray Center, Aksaray 68100, Turkey
}

\begin{abstract}
The main purpose of this study was to determine the changes in the water quality of Melendiz and Karasu streams, which recharge the Mamasin dam, and to evaluate its environmental impacts on the dam site that provides drinking water and irrigation demand in Aksaray city in the Central Anatolia of Turkey. The field researches were focused on estimating the main sources of contamination, determining and evaluating the changes in the water quality due to the direct wastewater discharges into the Melendiz and Karasu rivers, which recharge the Mamasin dam sites. During the study, water samples were collected from Melendiz and Karasu stream and Mamasin dam, and then, the physical and chemical analyses of water samples were conducted. The relevant in-situ and laboratory analyses were carried out during the dry and wet seasons. The results of the analyses showed that in term of the surface water quality criteria in terms of $\mathrm{NO}_{3}-\mathrm{N}$ value of both rivers and dam waters, the water quality is always considered as the 1st class in Melendiz stream, the 2nd class in Karasu stream and the 3rd class in Mamasin dam lake. Whereas, in terms of $\mathrm{NO}_{4}-\mathrm{N}$ values of both rivers and dam waters, the water quality is always considered as the 1 st class in Melendiz stream, the 2nd-3rd class in Karasu stream. The total organic carbon (TOC) range for Karasu river is usually from 20 $\mathrm{mg} / \mathrm{L}$ to $40 \mathrm{mg} / \mathrm{L}$. The high value of organic matter in the Karasu stream can be explained by the availability of intensive green wetlands around this water resource. Finally, the Ministry of Forest and Water Authority give some suggestions for estimating protection zones of Melendiz stream and Mamasin basin's area, such as using the results of environmental tracers to investigate the agricultural contamination, including more sophisticated applications of multiple-tracer analyses to evaluate the travel time of contaminants and estimate the boundary of protection zones.
\end{abstract}

Key words: Melendiz stream, Mamasin dam, water quality and pollution, Aksaray city, Turkey.

\section{Introduction}

Dams and streams have been used to provide a store of water for drinking, agriculture, industrial uses and household uses for thousands of years. Hydroelectric dams, additionally, act as an alternative to non-renewable energy resources that constitutes the majority of the world's energy [1]. In the 20th century, many dams were constructed around the whole world for covering several drinking, agriculture and industrial uses [2]. However, dams have drastic damaging effects on the environment and populations that live near the dam sites, and so have become the subject of great scrutiny, with organizations concerned

Corresponding author: Hatim Elhatip, professor, research fields: hydrogeology, hydrochemistry and water pollution. with environmental health, such as, World Wildlife Fund (WWF) and International Rivers Organization advocating the removal of old dams and the use of alternatives [3, 4]. Most of the human activity upstream can increase the nutrient level in the reservoir which may lead to eutrophication and eventually leads to the loss of most species in the reservoir [5]. This phenomenon occurs in Mamasin dam lake, which is recharged by two main water resources in the upstream side of the dam in Aksaray city at the Central Anatolian of Turkey. The Mamasin dam is at $17 \mathrm{~km}$ northeast from the Aksaray city center (Fig. 1).

The Mamasin dam is recharged by two main water resources. The major water recharge volume is mainly 


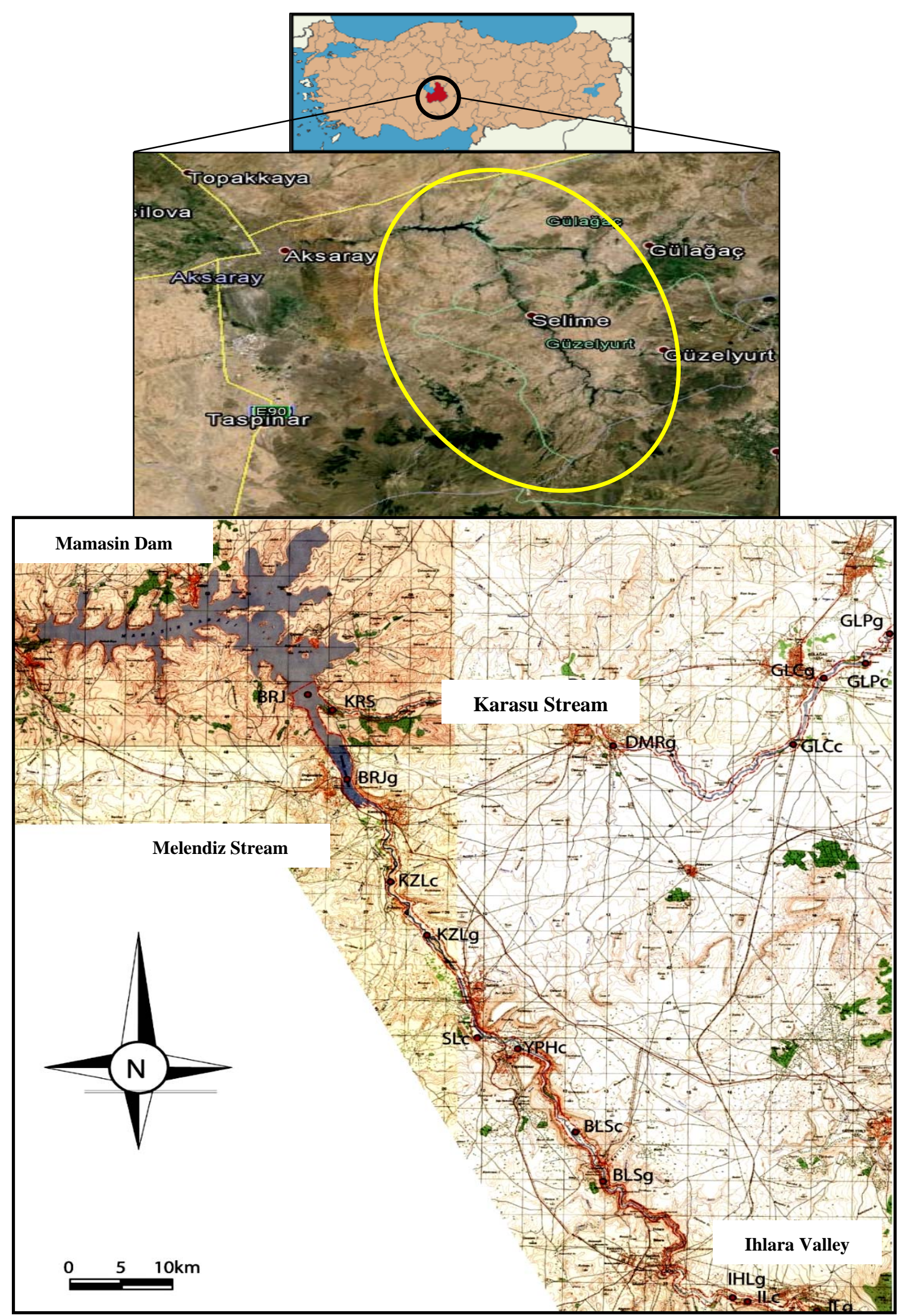

Fig. 1 Location map of the research site. 
supplied from the Melendiz stream, whereas the other water resource is the Karasu stream. Melendiz stream starts flowing from Niğde city, heading towards the southeastern edge of Aksaray city, crosses Ihlara valley, Mamsin dam and continue till the Uluirmak river that passing via Aksaray city. The Mamasin dam and Melendiz stream are considered as the largest drinking water supply of the Aksaray city. The Mamasin dam was constructed in 1961 for supplying irrigation water in Aksaray. Recently, this dam has been used for supplying drinking water to the central part of Aksaray city. The potential needs for drinking water of Aksaray city are seasonally changing from $450 \mathrm{~L} / \mathrm{s}$ to $550 \mathrm{~L} / \mathrm{s}$. The annual water potential of Aksaray city is about $12.5 \times 10^{6} \mathrm{~m}^{3}$. The maximum capacity of this reservoir is $0.17 \mathrm{~km}^{3}$. The watershed area the Melendiz at the Mamasin dams (which runs in the southeast-northwest direction across the Aksaray) is $1,383 \mathrm{~km}^{2}$. About $30 \%$ of the area is occupied by forest and $50 \%$ is cultivated.

The main objectives of this research were to determine the change in the water quality of Melendiz stream and estimate its environmental impacts on the Mamasin dam site, by discussing the main sources of contamination and the direct wastewater discharges into the Melendiz and Karasu rivers, which recharge the Mamasin dam sites, which mainly supplies the drinking water and agricultural demands of the Aksaray city.

\section{Materials and Methods}

During this research, the main water quality parameters of the domestic wastewater pollution were investigated. In order to reveal the current situation in terms of water quality of both Melendiz and Karasu streams, a total of 17 water samples (seven from Karasu, nine from Melendiz and one from Mamasin dam) was collected on a monthly basis starting from the downstream to the upstream side of the dam site (Fig. 2). The physical and chemical quality parameters of these water samples were analyzed during the periods between December 2014 and
November 2015.

Physical and chemical parameters of temperature, $\mathrm{pH}$, electrical conductivity (EC), dissolved oxygen (DO) and total dissolved solids (TDS) were measured in the field. The $\mathrm{pH}$ was measured using WTW-LT 330 Model pH and EC was measured by conductivity meters (Thermo Scientific Orion STAR A329 Model). Other chemical parameters, such as $\mathrm{Fe}^{3+}, \mathrm{NH}_{4}-\mathrm{N}$, $\mathrm{NO}_{2}-\mathrm{N}, \mathrm{NO}_{3}-\mathrm{N}$, total $\mathrm{N}, \mathrm{Cu}, \mathrm{Ni}$ and $\mathrm{Mn}$ were measured at the laboratories in Department of Environmental Engineering, Faculty of Engineering, Aksaray University. Suspend solid matter was measured by using a vacuum filtration system developed by World Health Organization (WHO)-American Public Health Association (APHA) [6].

The surface water quality of Aksaray is classified according to the WHO surface water standards, which include four mainly classes [6,7]:

(1) The 1st class: excellent. The total soluble salt content and the sodium percentage of this water are low enough that no problems should result from its use.

(2) The 2nd class: good. This water is suitable for use for most crops under most conditions. The extensive use of water in the 2 nd class on clay soil, where little or no leaching occurs, may eventually cause a saline or sodic soil problem. Normal rainfall will usually dilute the soluble salts and eliminate the risk of salt accumulation.

(3) The 3rd class: fair. Water of the 3rd class can be used with little danger in permeable, well-drained soils. The water table should be at least $3.05 \mathrm{~m}$ below the surface to allow the accumulated salts to be leached below the root zone by adequate irrigation, when rainfall is limited.

(4) The 4th class: poor. Use of this water is restricted to well drained permeable soils for the production of salt-tolerant crops. Excess water must be applied when rainfall is not adequate to cause periodic salt leaching. 


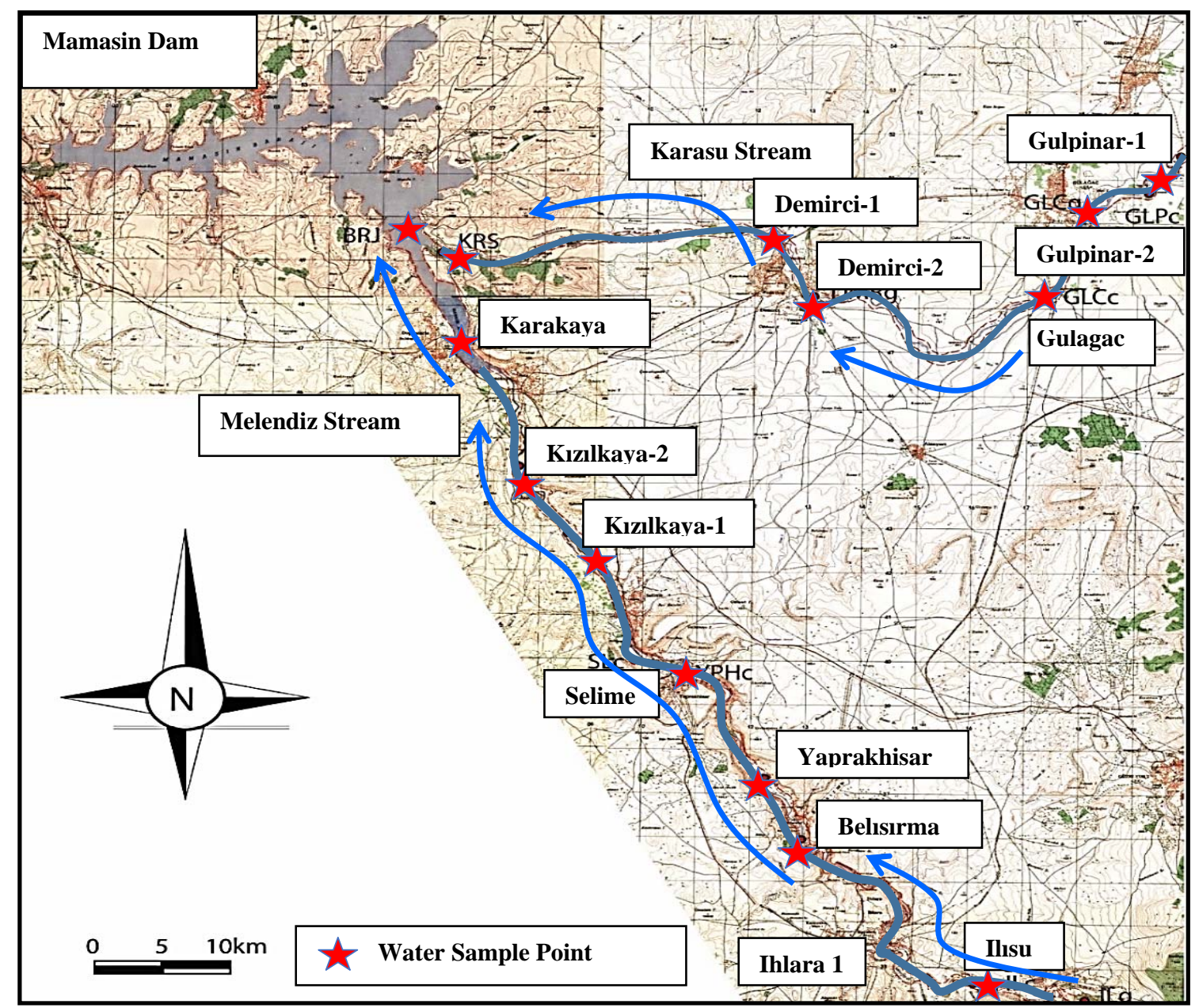

Fig. 2 General view of the water sources (Melendiz streams, Karasu streams and Mamasin dam) in Aksaray city.

\section{Results and Discussion}

\subsection{The Physical and Chemical Properties of the Water Resources in Aksaray City}

One of the main water resources in Aksaray city is streams of Melendiz and Karasu, which recharge the Mamasin dam lake. The Mamasin dam lake covers a surface area of about $16.20 \mathrm{~km}^{2}$. The minimum and maximum watered depth of the dam lake is $1,086.62$ $\mathrm{m}$ and $1,109.24 \mathrm{~m}$ above the sea level, respectively. The water quality at the dam site has been recently affected by the wide spread growth of industrial and agricultural activities.

The use of chemical fertilizers and pesticides in agricultural activities increases water pollution in the dam watershed. Surface water sources are extremely exposed to industrial and/or domestic wastes. The waste water is directly discharged into the Melendiz and Karasu rivers, which directly recharge the dam lake. All villages settled along the Melendiz and Karasu rivers do not have any sewerage systems and/or wastewater collectors/channels, thus all wastewater is conveyed directly to the Mamasin dam.

\subsection{Surface Flow}

The field measurements of Karasu and Melendiz include the depth of sampling points, the width and velocity/discharge of surface flowed. It was found that these parameters were affected by the variable seasonal climatic conditions. The flow measurement of Karasu and Melendiz streams were carried out from 
upstream to downstream sites. The Karasu stream was measured in the summer and autumn periods. The flow rate of Karasu stream changs from $0.1 \mathrm{~m}^{3} / \mathrm{s}$ to 3 $\mathrm{m}^{3} / \mathrm{s}$, whereas the flow rate of Melendiz stream changes from $0.7 \mathrm{~m}^{3} / \mathrm{s}$ to $7 \mathrm{~m}^{3} / \mathrm{s}$. The lowest and maximum flow rate was measured in August. A comparison of both water supply in terms of flow rate showed that the flow rate of Melendiz stream is higher than the volume of water carried by Karasu stream.

\subsection{Total $N$}

The water quality parameters of Melendiz and Karasu rivers, which feed the Mamasin dams, were investigated in terms of $\mathrm{N}$. The total $\mathrm{N}$ included nitrate $\left(\mathrm{NO}_{3}-\mathrm{N}\right)$, nitrite $\left(\mathrm{NO}_{2}-\mathrm{N}\right)$, ammonium $\left(\mathrm{NH}_{4}-\mathrm{N}\right)$ and total organic $\mathrm{N}$. Water samples of the surface, middle and bottom levels of the Mamasin dam and from the upstream and downstream parts of the Melendiz and Karasu streams are collected and analyzed for 11 months. The results of total $\mathrm{N}$ are given in Fig. 3, while the changes of ammonium $\mathrm{N}$ and nitrate $\mathrm{N}$ are given in Fig. 4. Considering the surface water quality criteria in terms of $\mathrm{NO}_{3}-\mathrm{N}$ value of both rivers and dam waters, the water quality is always considered as the 1st class in Melendiz stream, the 2nd class in Karasu stream and the 3rd class in Mamasin dam lake (Figs. 3a, 3b and 3c).

In term of the $\mathrm{NH}_{4}-\mathrm{N}$ contents, the water quality of Melendiz at any time of the year is always the 1st class, and the level of water quality of Karasu streams and Mamasin dam lake is always the 3rd class. In particular localities, the continuous discharges of domestic wastewater sources cause gradual increase in $\mathrm{NH}_{4}-\mathrm{N}$ values. Considering the surface water quality criteria in terms of $\mathrm{NO}_{4}-\mathrm{N}$ values of both rivers and dam waters, the water quality is always the 1 st class in Melendiz stream, 2nd-3rd class in Karasu stream (Figs. 4a and 4b).

Moreover, at shallow levels of Mamasin dam lake, the $\mathrm{NO}_{4}-\mathrm{N}$ values indicate the 1st class water quality, and at deep levels, it shows the 3rd class water quality.
The pollution conditions in Mamasin dam are much more tragic (Fig. 4c).

Especially during the summer months, the ammonia nitrification process is blocked, and stagnant water is collected at bottom level of the dam, oxygen-depleted at the bottoms reduces and the ammonia concentration increases. Low concentration of ammonia contents at the dam site was obtained in the desired shallow depths of the lake. But after certain chemical treatment processes, the ammonia contents in drinking water supplied from the treatment plants may still have some operational problems, in terms of taste and odor water quality parameters. The ammonia contents may have great important role in terms of aquatic ecosystems. According to the $\mathrm{pH}$ values of water, the ammonia is ionized in this water resource. The free form of ammonia is particularly more toxic and release increases in higher $\mathrm{pH}$ values [8].

The toxicity values of free ammonia for most of the fish are about $1 \mathrm{mg} / \mathrm{L}$. The total ammonia concentration on the water is rarely found even at these levels. At $\mathrm{pH} \mathrm{7,} \mathrm{the} \mathrm{free} \mathrm{ammonia} \mathrm{contents} \mathrm{in}$ $200 \mathrm{mg} / \mathrm{L}$ of total ammonia concentrations, is only 1 $\mathrm{mg} / \mathrm{L}$, when the $\mathrm{pH}$ values increase up to $9,30 \mathrm{mg} / \mathrm{L}$ of total ammonia concentrations may have free ammonia content of $1 \mathrm{mg} / \mathrm{L}$ approximately. While, the $\mathrm{pH}$ value increases, the amount of free ammonia will also rise further. Especially during the daylight hours, the heavy eutrophication of lakes may cause increases in the $\mathrm{pH}$ values of the lake, due to the experienced excessive of algae and other photosynthetic organisms, which may cause more quickly recovery of $\mathrm{CO}_{2}$ rates for the atmosphere during the photosynthesis processes. Related reactions to these processes are generally as follows:

$$
\begin{gathered}
106 \mathrm{CO}_{2}+90 \mathrm{H}_{2} \mathrm{O}+16 \mathrm{NO}_{3}+\mathrm{PO}_{4}+\text { light energy } \rightarrow \\
\mathrm{C}_{106} \mathrm{H}_{180} \mathrm{O}_{45} \mathrm{~N}_{16} \mathrm{P}+154.5 \mathrm{O}_{2}
\end{gathered}
$$

The higher formation of algae and other photosynthetic organisms in water may reduce the concentration of $\mathrm{CO}_{2}$ in this water, and consequently to get the equilibrium of $\mathrm{CO}_{2}$ budget for the atmosphere; 


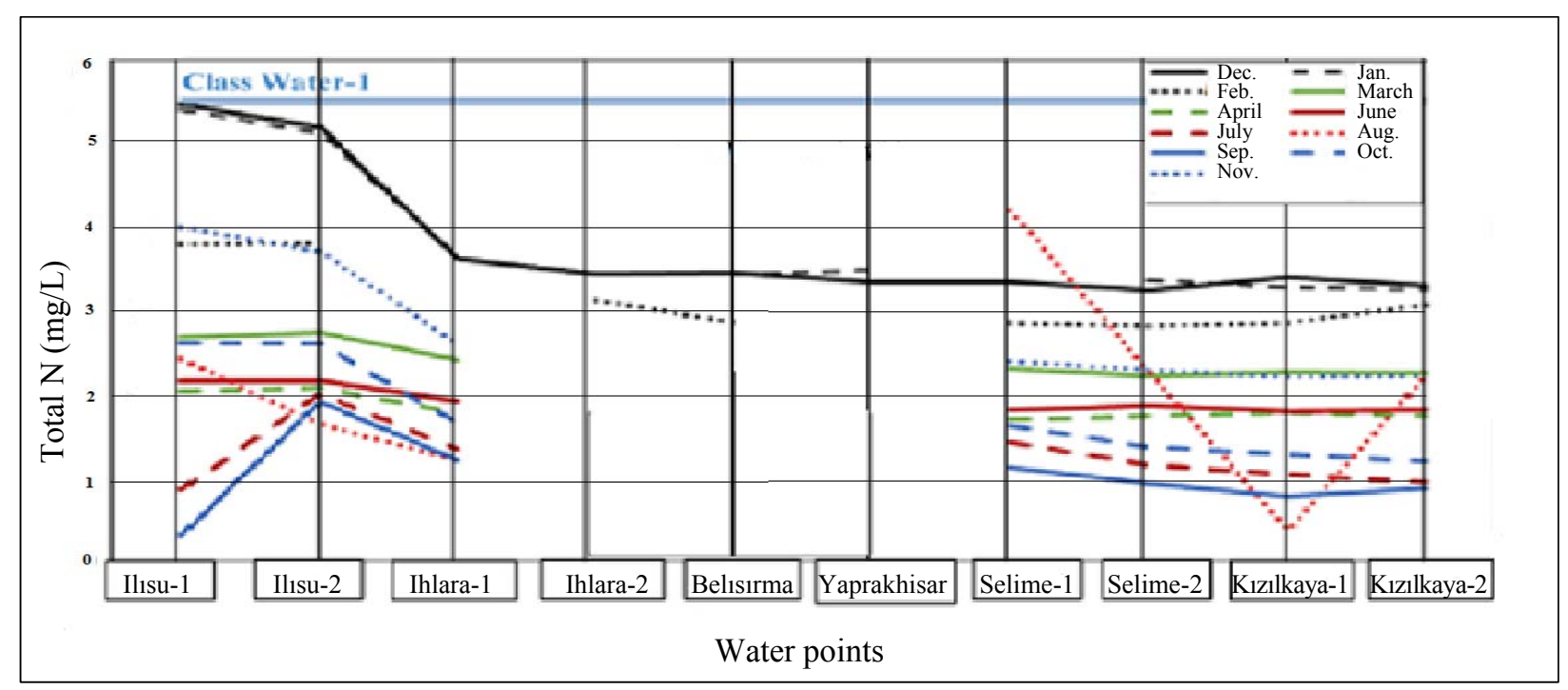

(a) Melendiz stream

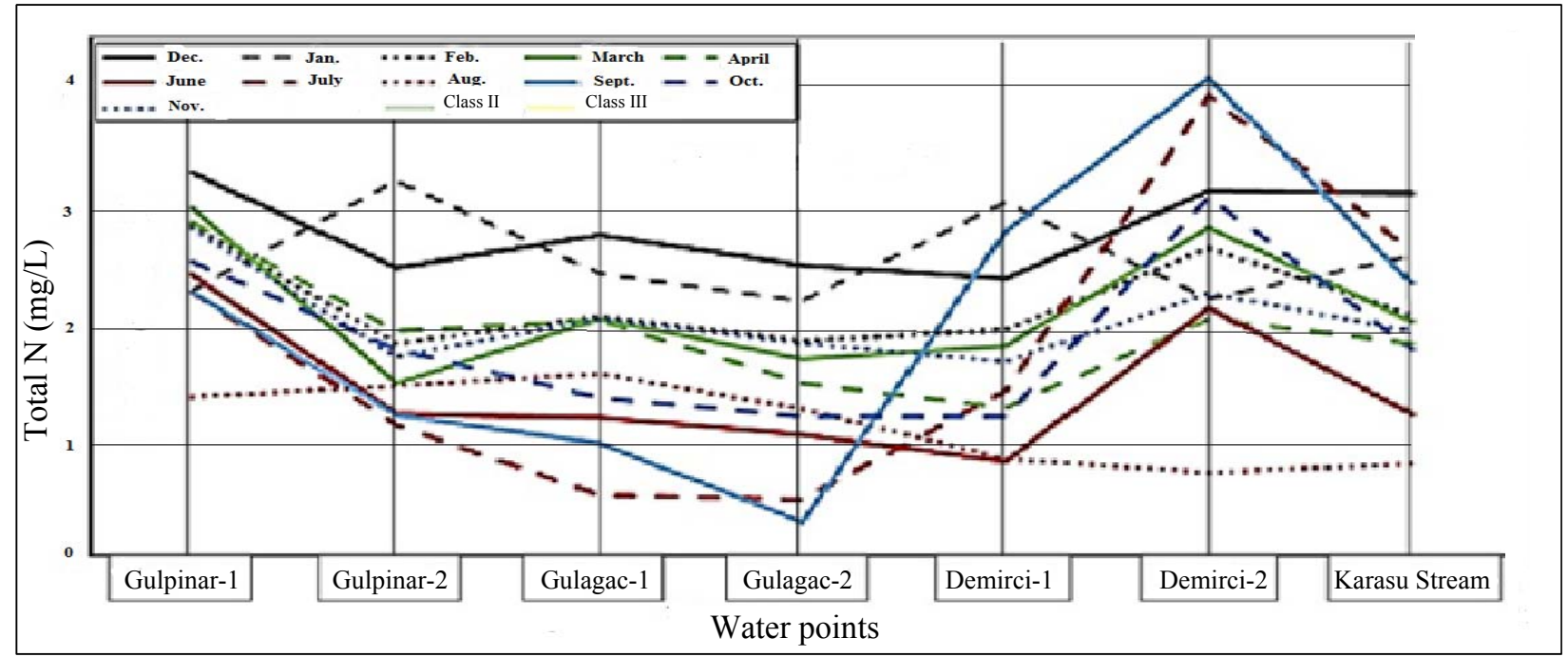

(b) Karasu stream

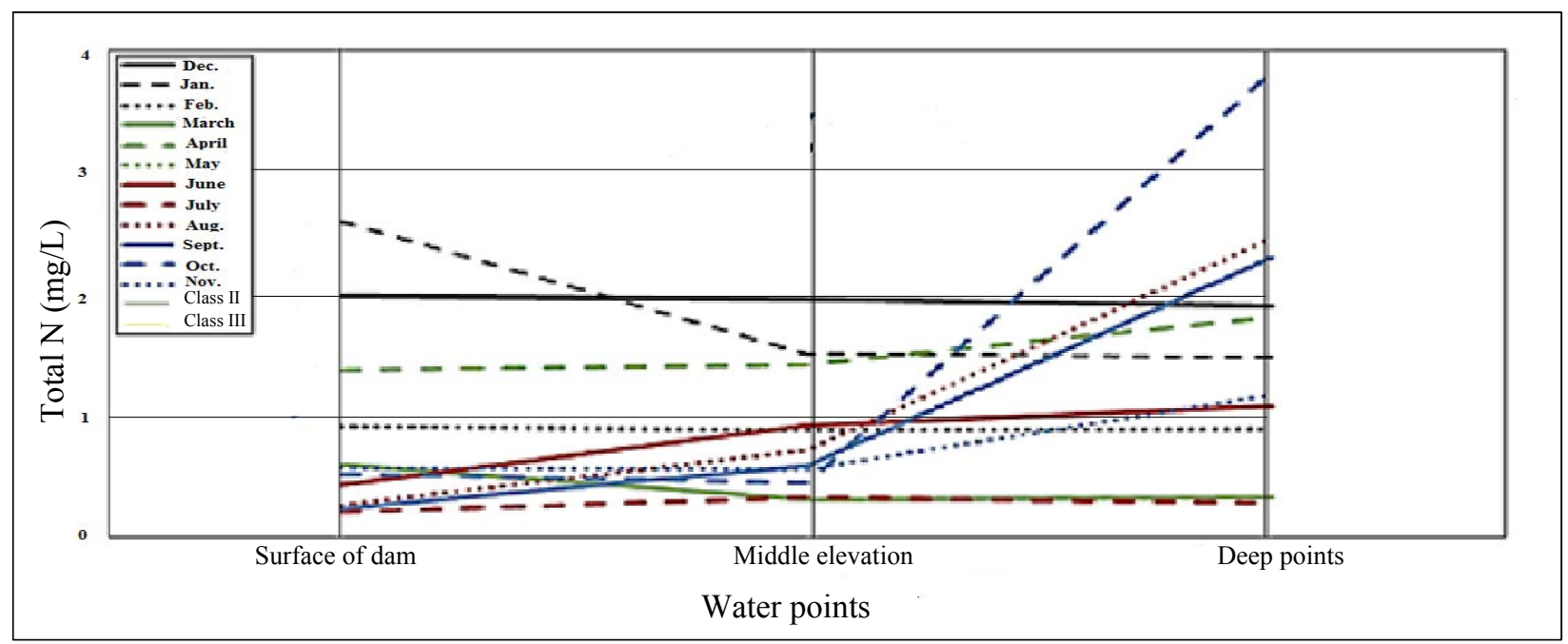

(c) Mamasin dam

Fig. 3 Total N in Melendiz stream (a), Karasu stream (b) and Mamasin dam (c) . 

Site in Aksaray City in the Central Anatolia of Turkey

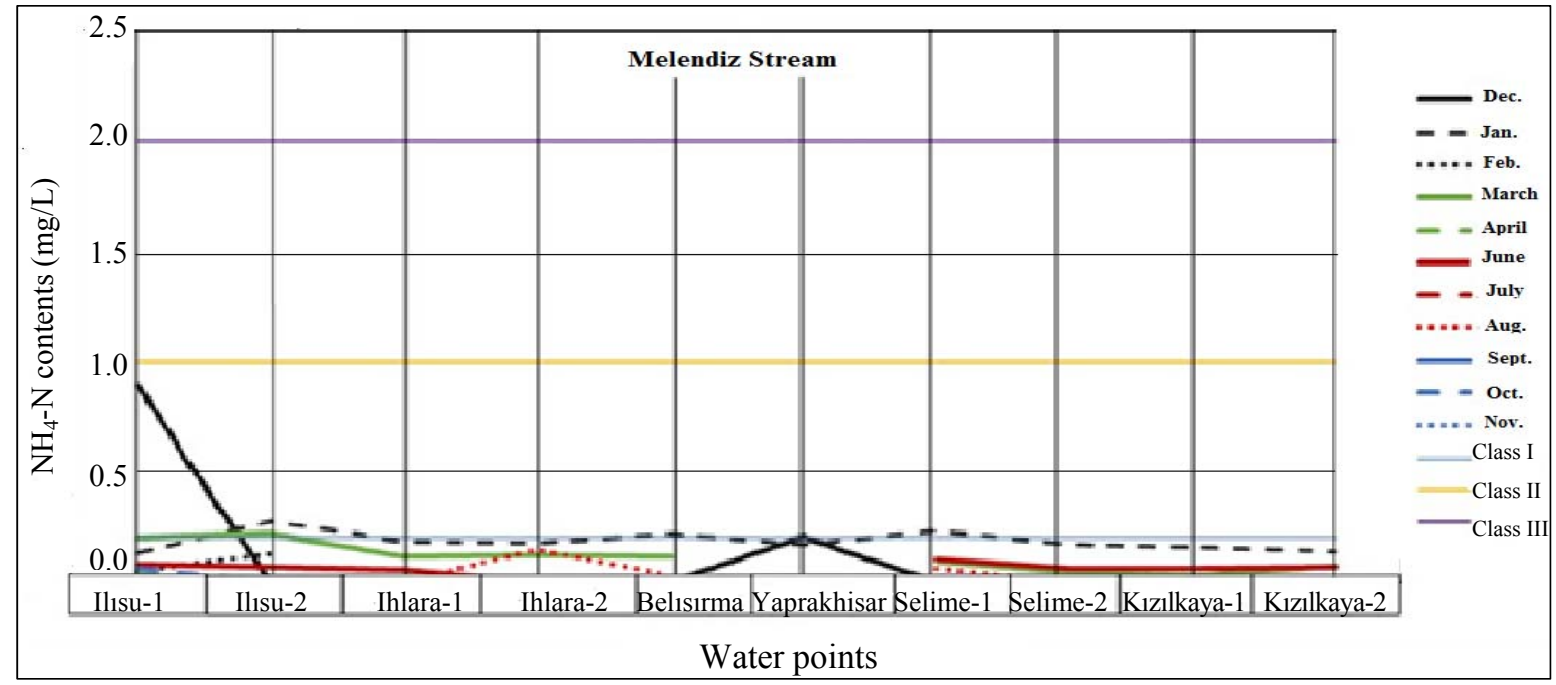

(a) Melendiz stream

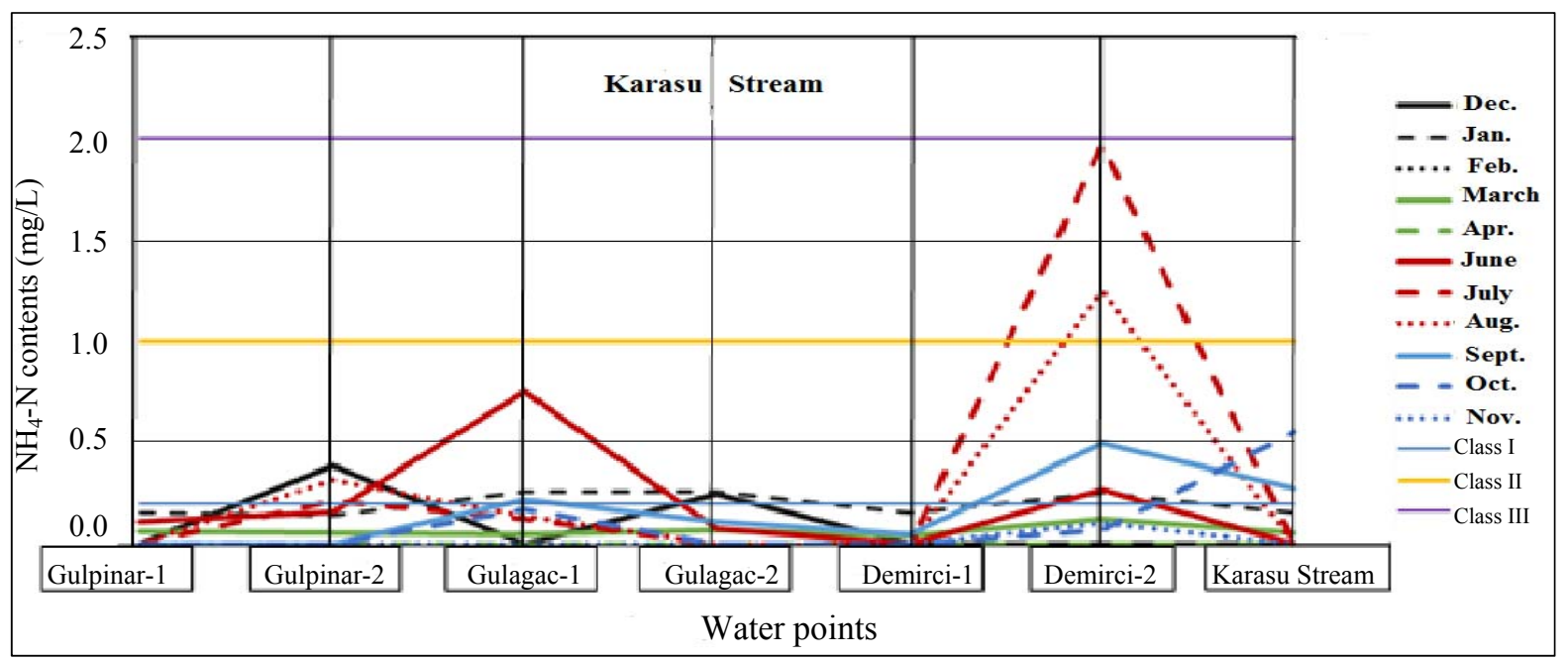

(b) Karasu stream

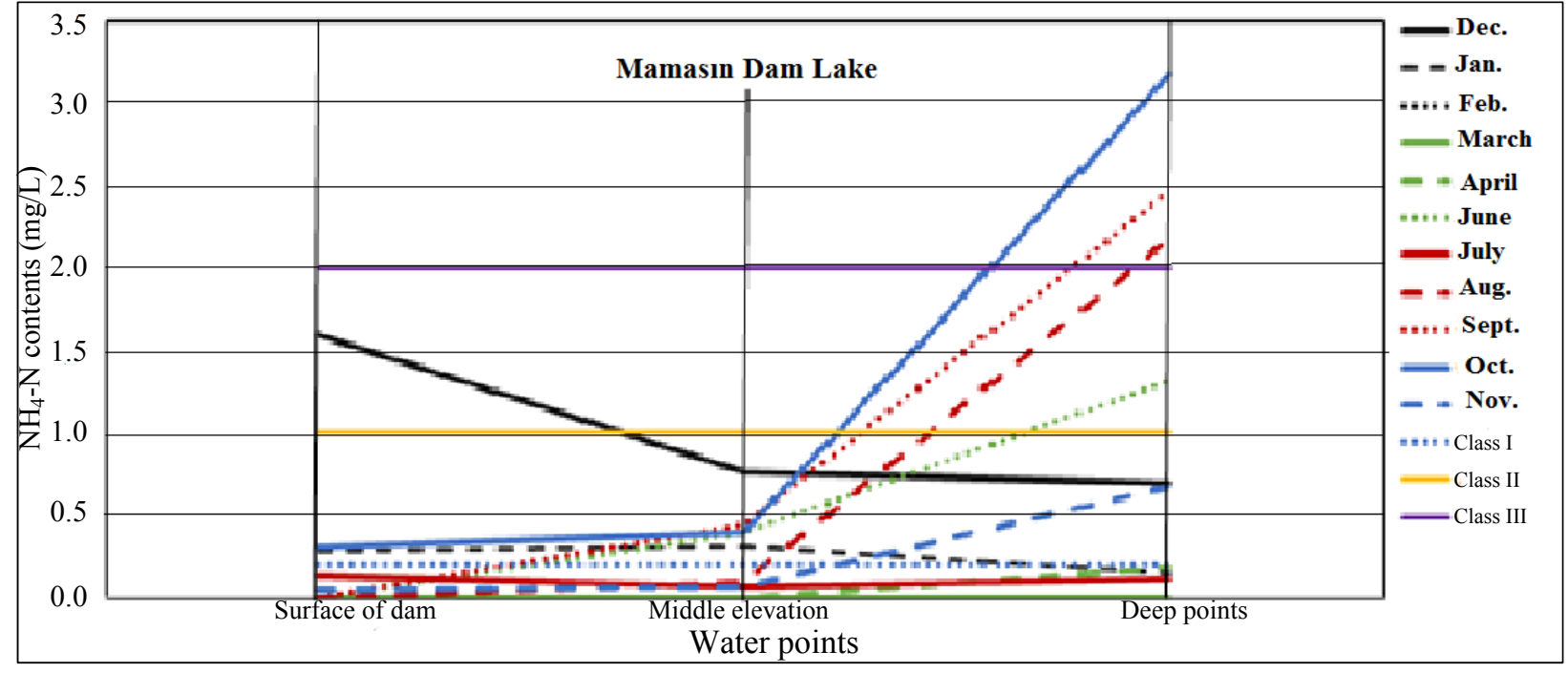

(c) Mamasin dam lake

Fig. 4 NH4-N contents of Melendiz stream (a), Karasu stream (b) and Mamasin dam (c). 
the lower $\mathrm{CO}_{2}$ content in of the water may further increase the $\mathrm{pH}$ values. When the $\mathrm{pH}$ value increases, the water alkalinity varies in different form, and photosynthetic organisms in water that may cover their $\mathrm{CO}_{2}$ demands of the bicarbonate and carbonate, respectively. Bicarbonate alkalinity will be turned into carbonate alkalinity, and later it may change to hydroxyl alkalinity. Water does not have excessive calcium contents or $\mathrm{CaCO}_{3}$ deposition, so the total alkalinity will not be changed. In case the algae in lake continued to consume more $\mathrm{CO}_{2}$ contents, the $\mathrm{pH}$ values may reach to 10-11 level, and in terms of the toxicity of ammonia and hydroxyl, this situation is very dangerous [9].

$$
\begin{gathered}
2 \mathrm{HCO}_{3}^{-} \leftrightarrow \mathrm{CO}_{3}^{2-}+2 \mathrm{H}_{2} \mathrm{O}+\mathrm{CO}_{2} \\
\mathrm{CO}_{3}^{2-}+\mathrm{H}_{2} \mathrm{O} \leftrightarrow 2 \mathrm{OH}^{-}+\mathrm{CO}_{2} \\
\mathrm{Ca}^{2+}+\mathrm{CO}_{3}^{2-} \leftrightarrow \mathrm{CaCO}_{3} \text { (solid) }
\end{gathered}
$$

In eutrophic lakes, algae and other photosynthetic organisms may produce $\mathrm{CO}_{2}$ in the dark times of the day. In this case, the opposite situation is experienced and the $\mathrm{pH}$ value decreases. At eutrophic lake, high $\mathrm{pH}$ and $\mathrm{O}_{2}$ values are always available during the day, but during the night, the opposite situation is experienced and low $\mathrm{pH}$ and $\mathrm{O}_{2}$ levels could be observed and/or measured. This case may cause a fatal effect on the $\mathrm{O}_{2}$ and the $\mathrm{pH}$-sensitive creatures, dependent living in the waters.

$$
\mathrm{CH}_{2} \mathrm{O}+\mathrm{O}_{2} \rightarrow \mathrm{CO}_{2}+\mathrm{H}_{2} \mathrm{O}+\text { chemical energy }
$$

\subsection{Changes of Total Organic Carbon (TOC) and DO Contents}

The results of TOC analysis of the water samples collected from the downstream area of the Karasu and Melendiz stream show that TOC concentration in Melendiz stream is lower than Karasu stream. The TOC concentration in Melendiz stream on December, representing the rainy season, is about $3-6 \mathrm{mg} / \mathrm{L}$. In July which represents the dry season, TOC concentration may increase to $1-19 \mathrm{mg} / \mathrm{L}$. In this case, due to the low flow rate in the summer time, the instantaneous wastewater discharge may cause a major change in water quality, in terms of TOC concentration. During the dry season, the wide range of variation in TOC concentration is mainly related to the low flow rates and metabolic activity in ambient conditions with ideal level of temperature and DO values. The TOC range for Karasu river is usually in $20 \mathrm{mg} / \mathrm{L}$ to $40 \mathrm{mg} / \mathrm{L}$. The high value of organic matter in the Karasu stream can be explained by availability of intensive green wetlands around this water resource (Fig. 5).

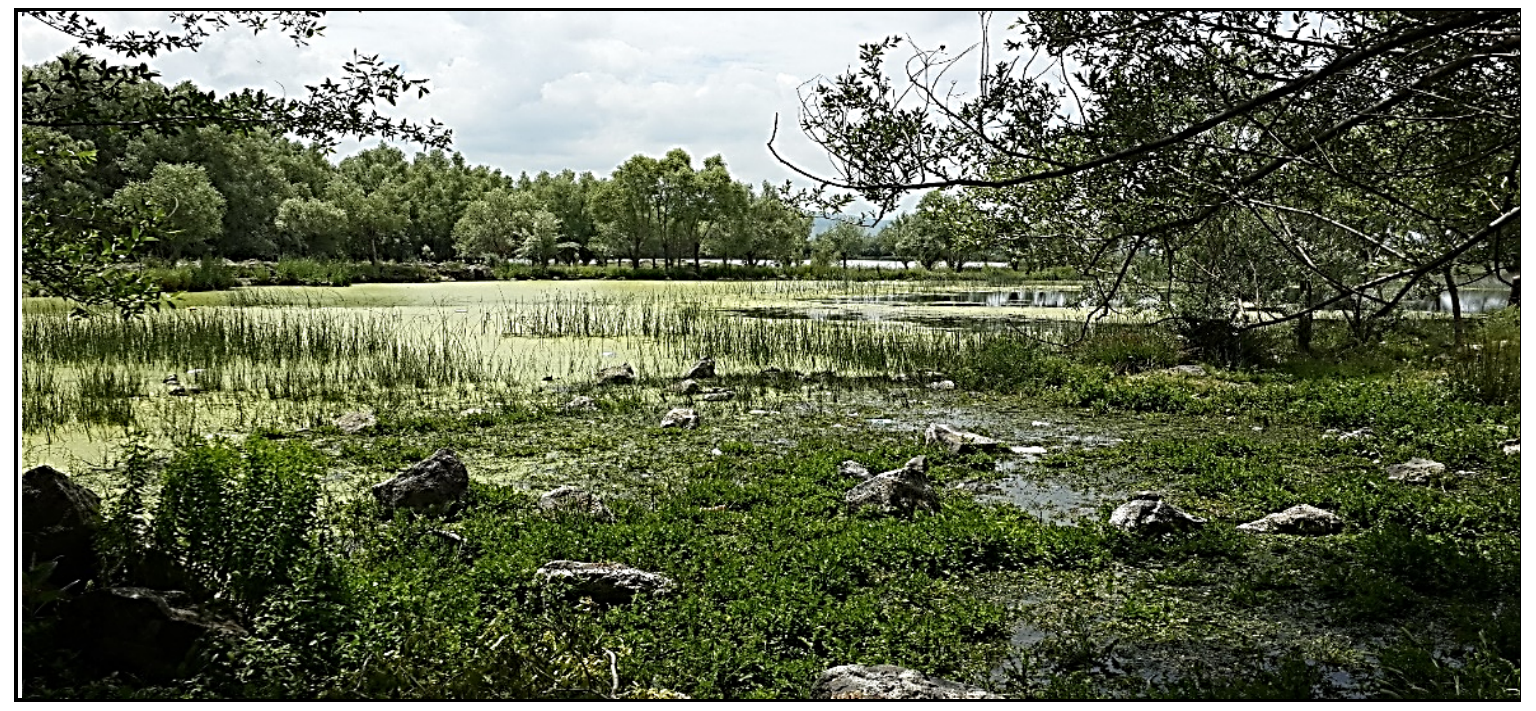

Fig. 5 The first outlet of Karasu stream. 


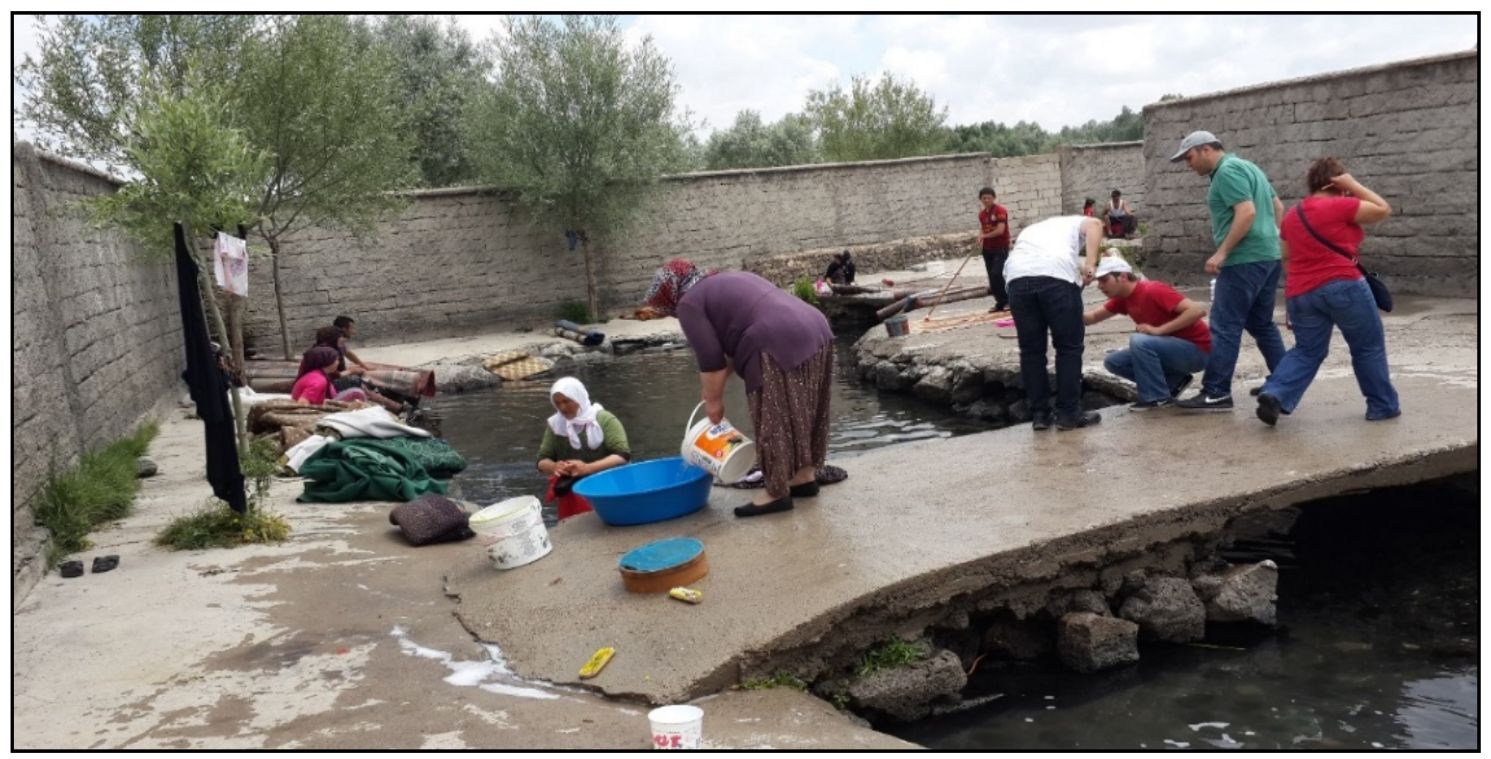

Fig. 6 Pollution exposures to Gülpınar site at the Karasu stream.

Wherever, the green wetlands usually have higher organic richness from the surrounding environments. The high concentration of TOC in the Karasu waters is coming from natural origin. This type of natural organic matter (NOM) may have cancerogenic effects from different disinfection by-products (DBPs) available in drinking water supply, so that this may form high risk potential to the human health. Here the DBP is the result from chemical reactions between organic and inorganic matter in water with chemical treatment agents during the water disinfection process. Therefore, in this context, water of Melendiz stream seems more advantageous in terms of water quality parameters. Pollution exposures to sewage and detergents in Gülpınar area at the Karasu stream are showed in Fig. 6. Considering the surface water quality criteria in terms of TOC concentrations in Melendiz stream, the water quality is always the $1 \mathrm{st}^{\circ}$ class during the winter, but during July and August, it may reach to the 3rd class (Fig. 7a).

While the surface watered quality criteria in terms of TOC concentrations in Karasu stream in all the period is always above the 3rd class (Fig. 7b).

The water quality of Mamasin dam lake, in terms of TOC concentrations values, was assessed as the 2nd to the 3rd class water type (Fig. 7c).

\subsection{Hydrochemical Evaluation of the Mamasin Dam Watershed}

The variations in temperature, EC, DO and TDS values of the different water samples are graphically evaluated for the three different periods. A general uniformity in chemical composition exists on temperature, EC and TDS values, which is related to sources and rate of the direct recharge from the outlet points of the Melendiz and Karasu rivers to Mamasin dam lakes. The general changes in the EC values of the surface water at the dam site are compared with the higher ion concentration changes in the dry and wet seasons (Fig. 8).

A significant increase in suspended matters existed especially on the end of the dry periods (August), due to addition of solids and sediments during rainy periods (October and December). Fig. 8 shows that the DO values did not change into the observed periods. DO values increased from the heavy rain periods. The decrease of DO values of December is related to the direct discharges of wastewater to dam lake. The general changes in the EC values of surface water from the research area are periodically compared with the higher ion concentration and changes of TDS during dry and wet seasons [7]. Results 


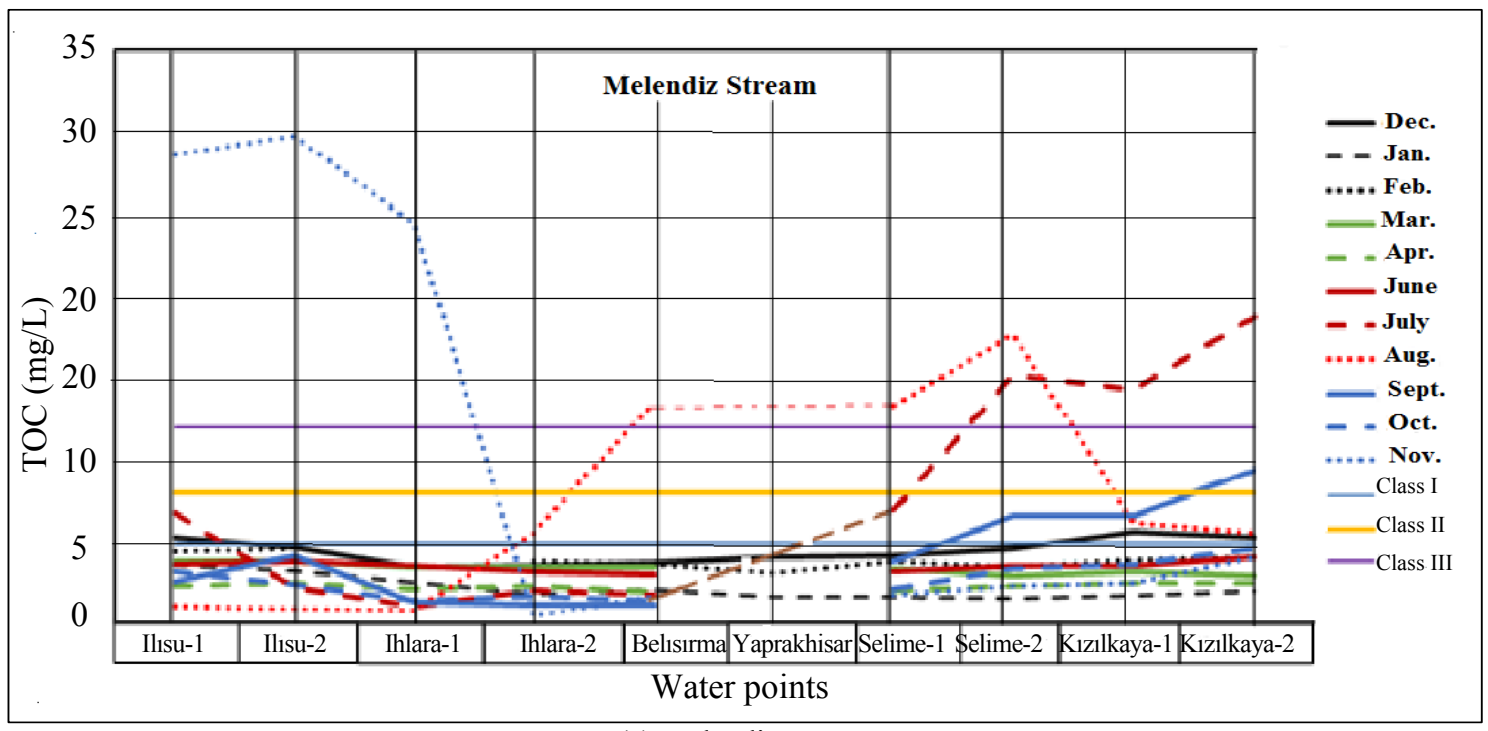

(a) Melendiz stream

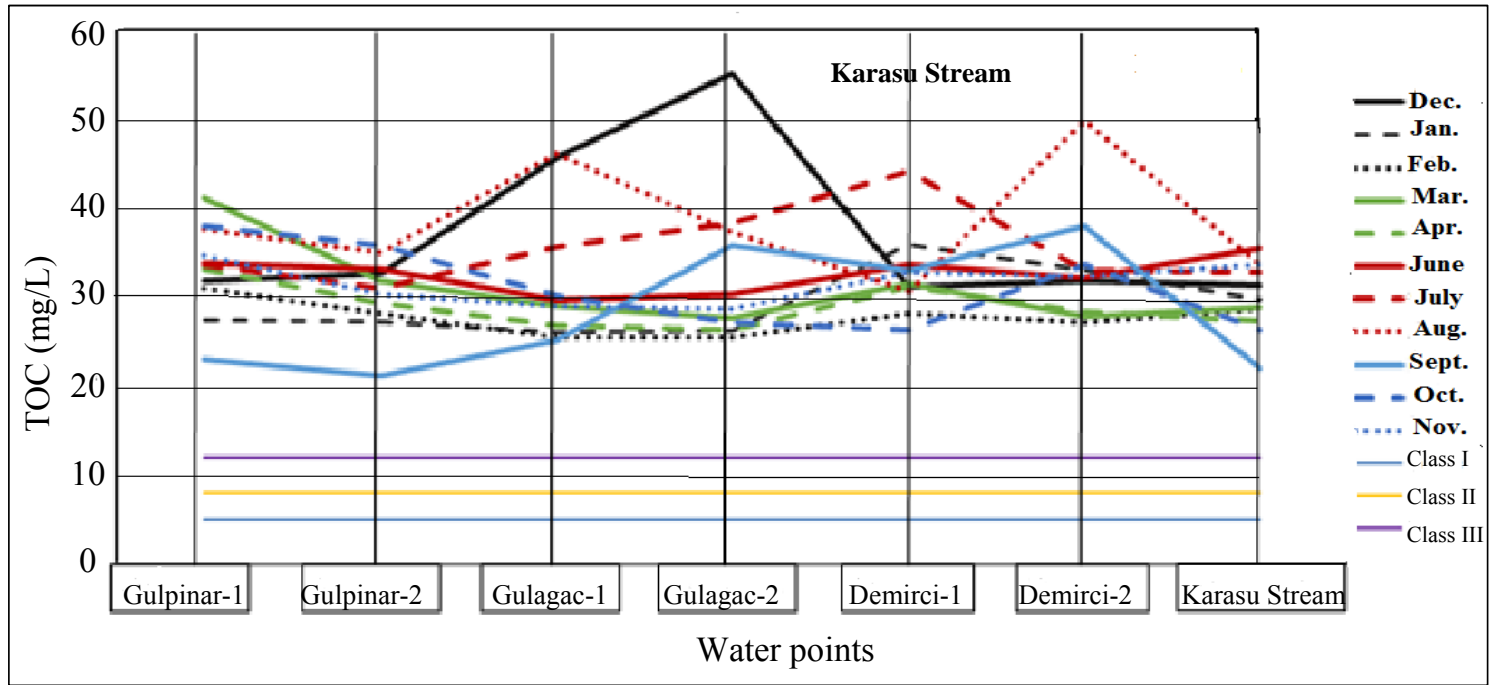

(b) Karasu stream

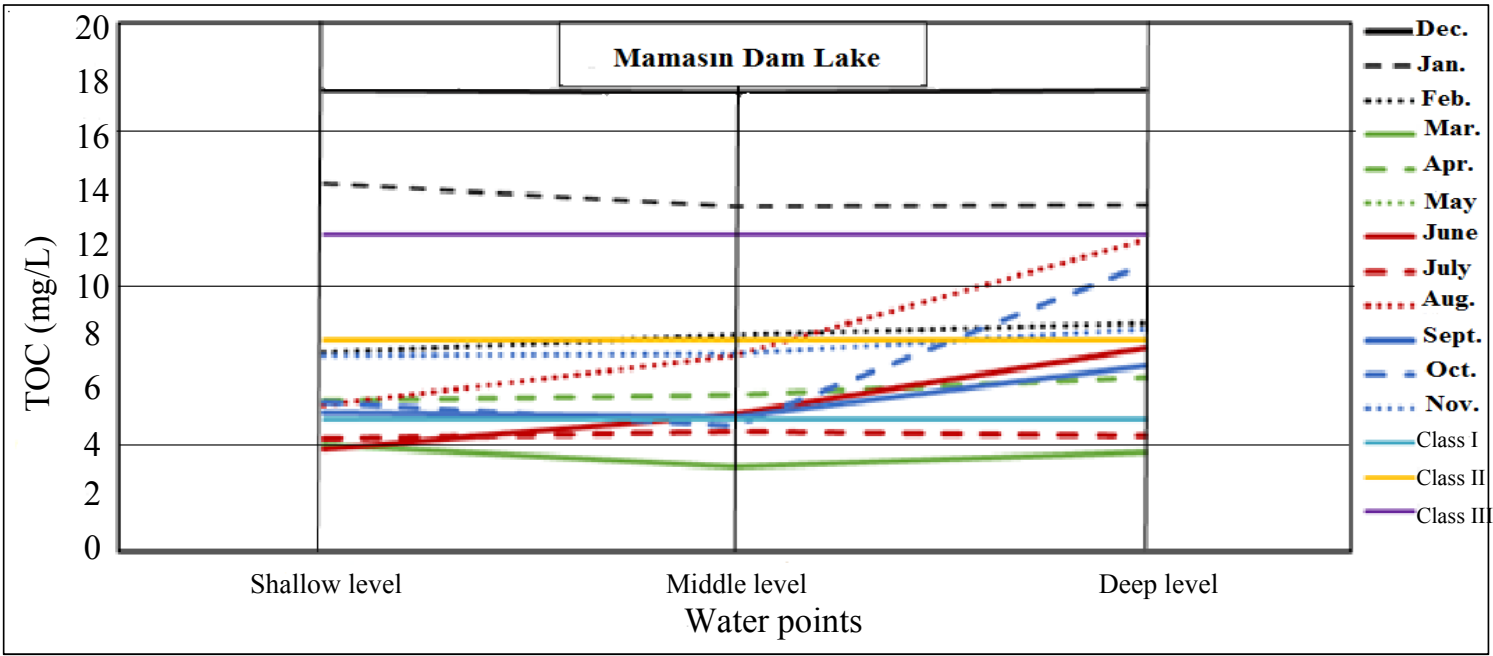

(c) Mamasin dam lake

Fig. 7 Changes of TOC concentrations in Melendiz stream (a), Karasu stream (b) and Mamasin dam lake (c). 


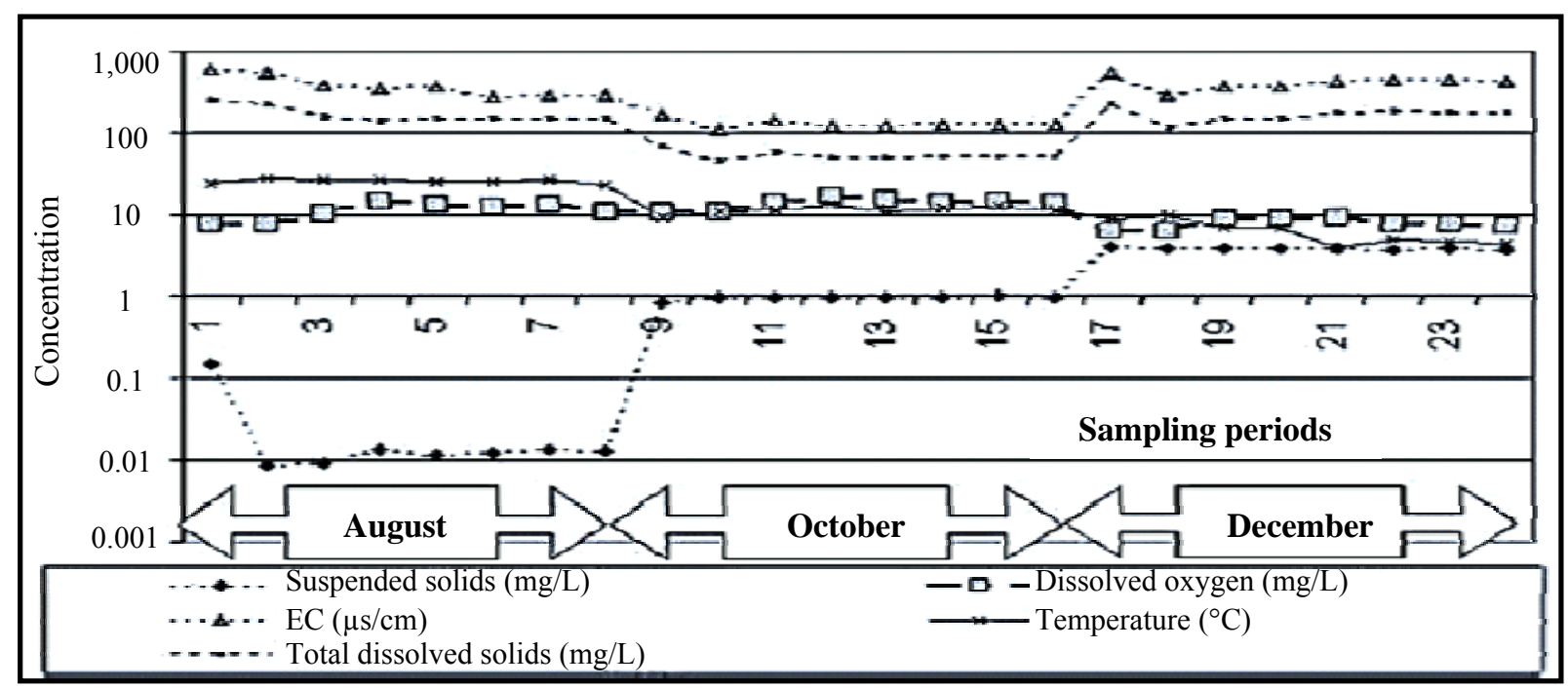

Fig. 8 Relationship between, suspended solids, DO, EC and temperature values for three different periods.

of analysis of water samples collected from the Mamasin dam site show that a periodical uniformity in chemical composition is existed, especially during the rainy periods, due to the source and rate of recharge [8]. Fig. 9 shows that high nitrate concentrations may occur due to leaching of $\mathrm{NO}_{3}$ from wastewater, fertilizers and biocides during irrigation of agricultural land in December.

Leakage from overloaded sewage networks are also sources of $\mathrm{NO}_{2}$ and $\mathrm{NO}_{3}$ pollution. The dam lake is highly contaminated by extreme $\mathrm{NO}_{3}, \mathrm{NO}_{2}$ and $\mathrm{NH}_{4}$ loads originating from irrigation drainage, sewage and deteriorating septic treatment system. The main source of nitrate in the study area is the nitrate from the continuous application of fertilizers in irrigation and from untreated waste waters directly discharged to the lake. The most common fertilizer used in the district is $\left(\mathrm{NH}_{4}\right)_{2} \mathrm{SO}_{4}$, it is liberally applied for the area. Through nitrification in the presence of $\mathrm{O}_{2}$, ammonium is transformed into nitrates as result of the following reaction [8]. Changes in heavy metal concentrations, such as $\mathrm{Fe}, \mathrm{Cu}, \mathrm{Ni}$ and $\mathrm{Mn}$ against water temperature is given in Fig. 10. The indirect effects have important implications for geochemical studies of water and rock interactions and can represent sources or sinks for a variety of problematic contaminants of such heavy metals and/or toxic trace elements [9].
Finally, the human activities affect the optimum yields of the Melendiz and Karasu rivers, which recharging the dam lake. This parameter is also important to the environmental balance and ecosystems in the region. High $\mathrm{N}$ and heavy metal concentrations in the dam site waters reflect the influences of direct liquid wastes, common usage of detergents and widespread farming and stock breeding practices around the research area.

Identifying the quality and quantity of pollutants originating from non-point sources for the water pollution is difficult and complex problems. The real solution to control the environmental impacts of pollutants in this dam watershed is the designation of adequate protection zones and better land use planning capable of controlling activities in such watersheds [10].

Future applications of environmental tracers to agricultural contamination study should include more sophisticated applications of multiple-tracer analyses to systems with shorter and longer transit times for both the surface and subsurface "saturated" zones to yield a better general understanding of these types of problems. The suggested protection zones for the Mamasin watershed and Melendiz stream are given in Fig. 11. The suggested protection zones are classified in three main protection areas: absolute protection zone $(0-250 \mathrm{~m})$, near distance protection zone $(250-750 \mathrm{~m})$, 
and long distance protection zone $(750 \mathrm{~m}$ to the boundary of recharge area).

\section{Conclusions}

The present study showed that Mamasin dame lake is highly contaminated by extreme organic nutrients materials (N-P compounds) loading, especially in the dry periods. Eutrification usually takes place in a static water mass. The continuous pollution in the Mamasin dam reservoirs may consequently reduce the quality of the lake waters. Common agricultural practices have caused substantial increases in groundwater recharge fluctuation and concentrations of major elements and a variety of heavy metals. The changes maybe directly increase due to fertilizers or other additives commonly used in the recharge area of Mamasin dam.

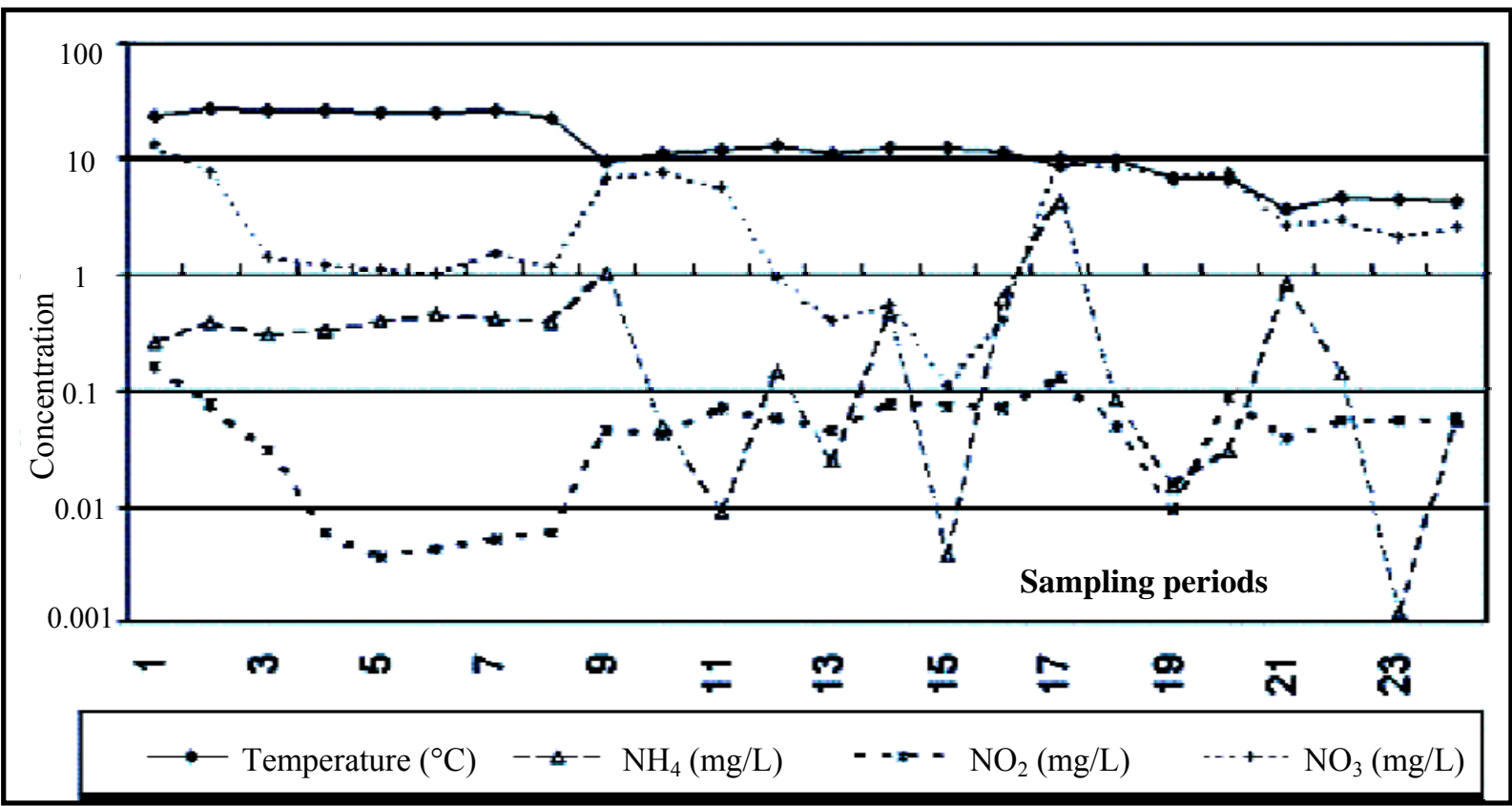

Fig. 9 Periodical changes in the nutrient contents (N) of Mamasin dam lake.

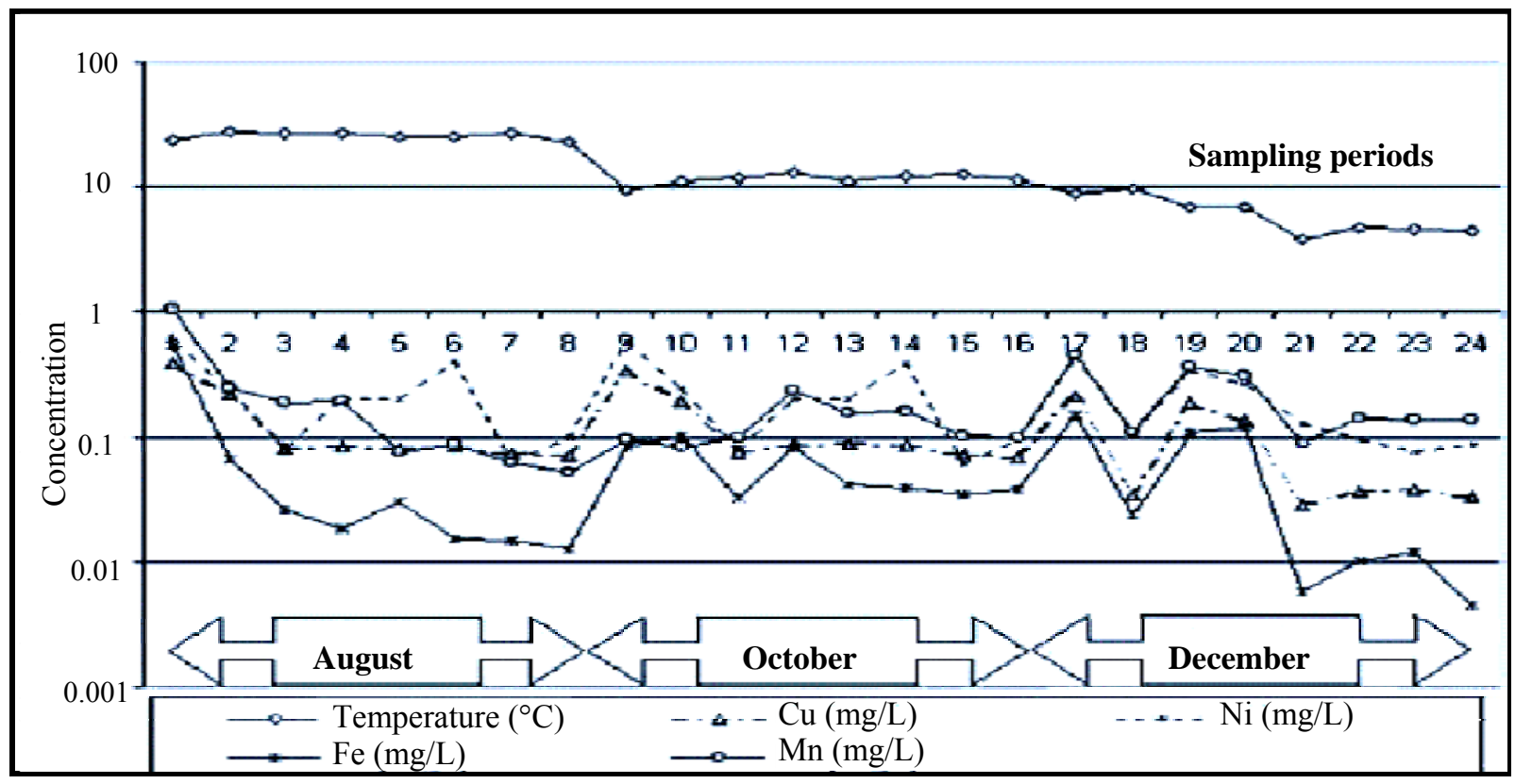

Fig. 10 Periodical changes of the heavy metal at Mamasin dam site. 


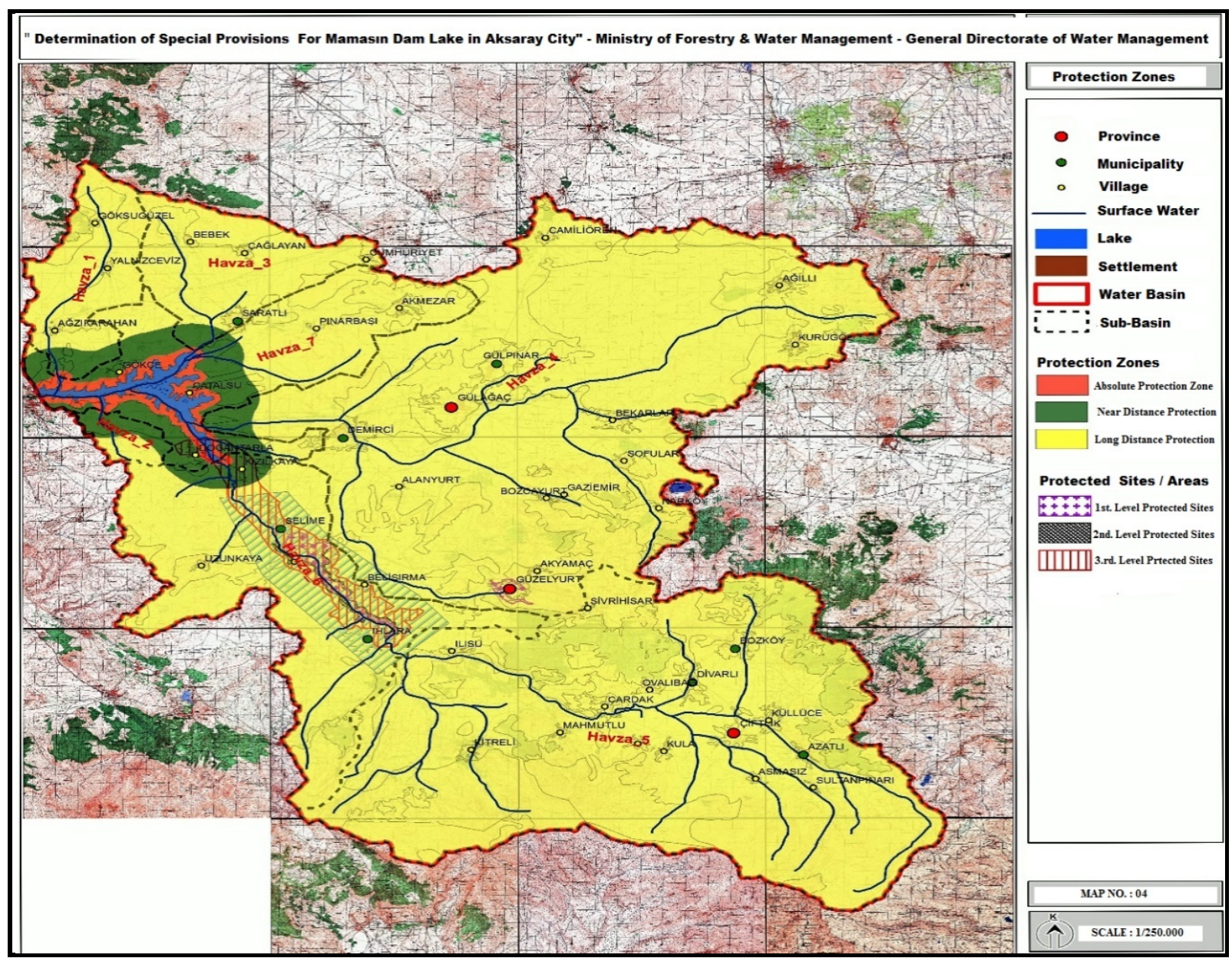

Fig. 11 The suggested protection zones for the Mamasin watershed and Melendiz stream.

Near the outlet points of the dam, such increases are typically, indirectly associated with fertilizer loadings or land disturbance through enhanced rates of leaching of natural sources of soils owing to physical and biological changes and increased acidity or ionic strength of agricultural recharge. Thus, high rates of $\mathrm{NH}_{4}$ and $\mathrm{NO}_{3}$ in groundwater have resulted in unnaturally high concentrations of chemical species released from aquifer materials by oxidation reactions in the saturated zone that the electron demand of $\mathrm{NO}_{3}$ in agriculturally contaminated recharge are commonly several times higher than that of dissolved $\mathrm{O}_{2}$ in uncontaminated recharging.

\section{References}

[1] UCSUSA. 2013. "The Sources of Energy." Union of Concerned Scientists, UCSUSA. Accessed November 23,
2013. http://www.ucsusa.org/clean_energy/our-energychoices/the-sources-of-energy.html.

[2] World Wildlife Fund (WWF). 2013. "Dam Facts and Figures." Accessed November 23, 2013. http://wwf.panda.org/what_we_do/footprint/water/dams_i nitiative/quick_facts/.

[3] International Rivers. 2013. "Dam Removal." International Rivers Accessed November 23, 2013. http://www.internationalrivers.org/campaigns/dam-remov al.

[4] World Wildlife Fund (WWF). 2013. "Dam Solutions-Alternatives \& Mitigation." WWF. Accessed November 23, 2013. http://wwf.panda.org/what_we_do/footprint/water/dams_i nitiative/dams/alternatives/.

[5] Lindström, A., and Granit, J. 2012. "Large-Scale Water Storage in the Water, Energy and Food Nexus: Perspectives on Benefits, Risks and Best Practices.” SIWI Paper 21. Accessed November 2012. http://www.siwi.org/documents/Resources/Papers/Water_ Storage_Paper_21.pdf. 

Site in Aksaray City in the Central Anatolia of Turkey

[6] American Public Health Association (APHA). Standard Methods for the Determination of Water and Wastewater, 15th ed.. Washington, DC: U.S. Environmental Protection Agency, 1134.

[7] Freeze, R. A., and Cherry, J. A. 1979. Groundwater. Englewood Cliffs: Prentice-Hall, 553.

[8] Elhatip, H., Afsin, M., Kuscu, I., Dirik, K., Kurmac, Y., and Kavurmac, M. 2003. "Influences of Human Activities and Agriculture on Groundwater Quality of Kayseri-Incesu-Dokuzpınar Springs, Central Anatolian
Part of Turkey." Environmental Geology 44 (4): 490-4.

[9] Gülbahar, N., and Elhatip, H. 2005. "Estimation of Environmental Impacts on the Water Quality of the Tahtalidam Watershed in Izmir, Turkey." Environmental Geology 47 (5): 725-8.

[10] Ministry of Forestry \& Water Management (MFWM). 2016. Determination of Special Provisions for Mamasin Dam Lake in Aksaray City. General Directorate of Water Management, Ankara. 